\title{
Terrorism as a Global Security Threat
}

\author{
Armin Kržalić, Nedžad Korajlić \\ University of Sarajevo, Sarajevo, Bosnia and Herzegovina
}

\begin{abstract}
When and how does the ultra-right-wing terrorism period close as their mean in politics with the goal of deterrence and the destruction of the capitalist order? Why does the "Arabian jihad" shift its priorities from the "close enemy" to the "far enemy"? Why did terrorist violence appear more often, in the last couple of decades, in the countries where Muslims are the majority, or why are the perpetrators, in terms of terrorist acts, mostly Muslims? These are the questions which are in the academic discussion centre and analysis of our paper. The paper identifies the causes and discusses the "us" and "them" polarization. The goal is to explain what is behind these paroles through the analysis of world's authors: "War against terrorism", "Unity of a nation", and "The just war". From a theoretical and empirical point of view, emphasizing of the Islamic component in terrorism is unfair at least. We used qualitative research methods, including the desk research, to obtain necessary data to give answers on our research questions.
\end{abstract}

Keywords: terrorism, terror, colonialization, jihad, civilization

Expectations that globalization could reduce the gap between the rich and the poor is a wrong premise and is equal to the expectation that terrorism could disappear in the new world order. Because of that, we view terrorism as a huge challenge to global security and a global security threat. When talking about terrorism as a global security threat we view terrorism as an agent, because terrorism is nor a philosophy or movement. Such deliberation is joined by Šikman (2006) as well, who views terrorism as a global security threat to the world, considering that terrorism is one of the most dangerous forms of state, region, and international community in whole, security endangerment, and, as such, represents a convincing security threat of certain states and a global threat to the security of the international community.

When viewing from different perspectives, which we will analyze below, one act is considered as terrorism and liberation at the same time, we chose not to define terrorism. In the paper we will research the history of terrorism, misuse of terrorism by dishonourable politics, and through the analyses of world authors, explain what is behind the paroles: "War against terrorism", "Unity of a nation", and "War for justice". We will not analyze and list all the definitions for the mentioned term.

\section{Meaning of the Word "Terror"}

The word "terror" originates from the Latin language, and it makes the base, or the root, for the word "terrorism". However, we trace the origin of this word to the Indo-European root "tras", what means shivering

Corresponding author: Armin Kržalić, Ph.D., professor, Faculty of Criminalistics, Criminology and Security Studies at the University of Sarajevo, Sarajevo, Bosnia and Herzegovina; research field: security studies.

Nedžad Korajlić, Ph.D., professor and dean, Faculty of Criminalistics, Criminology and Security Studies at the University of Sarajevo, Sarajevo, Bosnia and Herzegovina; research field: security studies. 
caused by fear. It is obvious that it is about a planned use of violence or violent threats to fulfill political, religious, or ideological goals. According to the foreign word dictionary (Klaić, Domović, \& Anić, 1985), "terror" indicates the provoking of fear, horror, dread, use of physical violence to destroy enemies, while the term "terrorism" means the conduction of terror, governance with intimidation, tyranny; destruction of enemies using the cruellest means (persecution, oppression, killing, etc.). Modly and Korajlić (2002) view terrorism as an "act of intimidation, violence directed towards viewers, including those in political and media life". According to them, contemporary terrorism is a danger for innocent people. To simplify, a more concise understanding for the mentioned words gives Abazović (2002) who says that "terrorism is a crime, and nothing but a crime, terrorists are criminals, and nothing but criminals (they are not idealists, nor heroes, nor freedom fighter, nor protectors of religious or national interests, nor..., nor...)".

\section{Terror as a Weapon for Oppression and Wars}

Terror as a weapon for oppression and wars was used through history starting with Plato, Aristotle, and Cicero, who celebrated the murder of unjust rulers, calling for other Romans to join him in the celebration. The Romans believed that killing of unjust rulers (tyrant kills) was the best venture, especially if the killer was close to the tyrant ${ }^{1}$. Most of the contemporary theorists connect the word "terror" (terreour, terror) to the events during the French Revolution (1789-1795) to point out the state of general fear developed intentionally for political purposes. The people who advocated the revolution, upon its realization, proudly called themselves "real terrorists" (vraishommes de terreour). During this period, the term terrorism appeared which marked the activities of the new government. This term was transferred to the rest of the world. The famous English philosopher of the XVIII century, Edmund Burke, labels the carriers of the French Revolution as terrorists. In a similar context, terrorism refers to the forms of violence the French government executed upon political opponents, nobles, their families, and sympathizers, but also common folk ${ }^{2}$.

This points out that terrorism gained a political dimension. Another confirmation for the appearance of the political dimension of terrorism during the period of the French Revolution, can be found by Robespierre Maximilien, the author of the Human Rights Declaration and one of the most eminent persons of the French Revolution, in his attempt to justify the revolutionary terror of the Jacobins, steadfastly conducted his motto that "the Revolution government is despotism of freedom against tyranny". Therefore, in the name of freedom, he insists on the despotism of the rulers, and despotism is only one form of state terrorism, or terrorism of the governing ideological or political elite, or oligarchy (Anic \& Goldsten, 2000, p. 1473).

Terrorism, as a form of combat, is used by certain groups to achieve goals which are mostly impossible to identify. However, in most cases, behind a terrorist act stand political issues. We can see that the term terrorism is long known, and it represents a historical phenomenon. As such, it has no dimension, does not have borders in time and space, can occur anywhere at any time, and can be spread on a local, regional, or global level. Terrorism reached its peak during the middle of XIX century in Western Europe and Russia. It was manifested through violent attacks, from assassinations of highly ranked persons to planting of explosive devices. It is

\footnotetext{
1 Romans appreciated the courage of Brutus in that way, which saved them from the arbitrariness of Julius Caesar.

2 The revolutionary court imposed 1,380 death sentences during the first 50 days of its activity, and it is believed that during the terror period, which was short-lived (almost two years), about 40,000 people were killed and about 300,000 were imprisoned (France, according to assessments, had about 27 million citizens at that time) - the terror mostly reflected on the citizens and peasants, nobles, and priests who were punished amounted to $8.5 \%$.
} 
believed that only in Russia more than 7,000 officials and security bodies were killed, including the emperor ${ }^{3}$. The anarchists called themselves terrorists without any shame and viewed their tactics as terrorism openly. On the second place we can mention the assassination of Austro-Hungarian archduke Franz Ferdinand, what started the avalanche of the First World War. Dominique Venner views this act as a break of the idea that monarchy should be restored in the empire where Slovenians, Croats, and Bosnians will be united in an autonomous community, while Serbs lost the only person who could potentially stop an armed conflict between Austria and Serbia (Venner, 2005, p. 34).

By the end of the XX century systematic terrorist attacks appear as a mean of terror, but in such extent modern era has not seen. Systematic terrorist attacks were used during the war in Bosnia and Herzegovina and were mostly directed against civilians. The experience of the citizens of Sarajevo, Bihac, and Tuzla tells that the Army of Republika Srpska exposed them to what were systematic terrorist attacks, which were like an extended terrorist campaign in terms of aftermath (Taylor \& Horgan, 2003, p. 89). Instead of the famous terrorist car bombs (like the one used by the Provisional IRA, in London), the explosions were caused by grenades, and single attacks on civilians were conducted by snipers. On the psychological side of such acts we can find elements of terrorism. Such acts were especially expressed in conscious choice of children as sniper targets. The reason for the mentioned was not the fact that the children would have a role in war, but on the contrary, killing of children was believed to be an efficient way of spreading fear and dispiritedness between the populations. Broader war goals were achieved with terrorist violence.

As a result, until the seize-fire at the beginning of 1994, one or two kids were killed daily in Sarajevo by the hand of the occupying army (the army of the Republika Srpska, chetniks, mercenaries, and volunteers), and it is believed that 20-25\% mostly suffered because of snipers. About the four-year blockade (Spahić, 2014) and terrorizing of Sarajevo tells the final verdict for Dragomir Milošević, the general of the army of Republika Srpska, by the Hague Tribunal. General Milošević (68) was declared guilty in November 2009 in five points of the indictment - terrorizing of the population in Sarajevo, killing of civilians and other inhuman acts during the artillery and sniper campaigns on civilians in Sarajevo from the position of the Sarajevo-romanijski corpse of the Army of Republika Srpska under his command between 1994 and 1995. Also, the Hague Tribunal declared Ratko Mladic guilty as well, the war commander of the Army of Republika Srpska in eight points of the indictment like terrorizing of civilians as breaking of war rules, attacks on civilians, and taking hostages as breaking of war rules.

Therefore, a question arises: Did these characteristics of terrorism change over the years, as a form of terror, and is a change probable in the future?

\section{Panta Rei-Everything Flows If You Wait Enough}

Terrorism did not change much during the last century, and almost not at all in the last 25 years. The first aeroplane kidnapping occurred in 1931, while terrorism reached its peak with the first kidnapping with a goal of political extortion in 1968. First car bombs were used in 1947 in Palestine, while the first terrorist bomb in an airplane exploded in 1955. Immediately at that time, in Europe, it appears first ultra-left groups like the Red Brigade, Red Army Faction, whose actions showed that terrorism was a mean in their politics, and the goal - destruction and intimidation of the capitalist order. This period ended at the beginning of the 1980s, and

\footnotetext{
3 The anarchists assassinated the emperor Alexander II in 1881, what led to the dissolution of the organization "Narodnaya Volya".
} 
opening of confidential documents of certain intelligence and counter-intelligence agencies showed that, during the Cold War, a great number of terrorist organizations were under the control of the security systems of the blocs, with a purpose to achieve goals at the expense of the opposing side.

After the end of the Cold war, and the weakening of the mentioned groups, it can be said that it was obvious to look for the opening of a new security problem. Israel did not stand still, and with USA and France as allies, invaded Lebanon what marked the beginning of the Lebanon Civil War, who clearly picked the side of the Christian forces what created and intensified the opinion that the USA and the West are enemies to the Muslim civilization. Obviously, such state was not enough, and they went on to raise the tensions between India and Pakistan in terms of Kashmir and Jammu, in order to create such circumstances where the Muslim world is not only in conflict with the West, but also with the Hindu and Orthodox civilization. These events overshadowed the terrorist acts conducted by racist right-wing groups in Austria, Germany, Sweden, and elsewhere, against Muslim citizens, as well as gang street attacks in Marseille, Berlin, Oslo, and Stockholm (Bjorgo, 1997).

By analyzing the religious background of the terrorist attacks in the far past (long before Islam, that is often marked as one of the main motive generators for such attacks), we found out that the earliest terrorist activities were conducted by the Sicarii (Greek-sikarioi, "people with daggers") ${ }^{4}$, as an extreme group of the Jewish Zealots. This Jewish group led an open campaign against Roman rule in Palestine, against all Jews who cooperated with Roman government, and against Mongols. In Masada, during 73, they used to commit suicide, rather to surrender to the Roman army (Laqueur, 1997).

In India, during the VII century, a religious cult existed, which spread terror with ritual killing of people and sacrificing them in honour of the Hindu goddess of fear, Kali. Outlaws, killers, the Hashashin (Arabian-hashshashun, "hashish users", "killers") were a sect which operated since 1090 to 1256. Their missions were to spread fear among enemies through terrorism and to assassinate their key political figures. Most of the time, they infiltrated the enemy lines where they themselves would suffer during the mission, what they were prepared for. A group with the same name started to spread from the Alamut Castle, "the eagle's nest", in the north of Persia, near the Caspian Sea, and they found first support among the mountain tribes who were out of any political influence. These killers based their empire on the ideology of Ismailism ${ }^{5}$, a group which turned away from the universal mission of Islam, and the authentic learning of the Islamic religion. Among their victims were highly ranked Muslims, Christians, Jews, and other (the Seljuq vizier Nizam al-Mulk, crusaders, Conrad of Montferrat - the king of Jerusalem, while Salahuddin, an Islamic general, managed to survive) $)^{6}$. The Hashashin Empire was destroyed during the Mongolian conquest, but the group survived even nowadays. They managed to establish a rule system again, and found their place in Persia (Syria and Iran), and with their persuasive abilities, in India among the Khojas.

\footnotetext{
4 This religious sect acted in Rome during 44 B.C.

${ }^{5}$ Isma'ilists - a sect which is considered to belong to the Shia, a branch in Islam. Such classification, however, can be wrong. Its unique features rather a metaphysics of Isma'ilism. The group is a manifestation in the Islam of the Persian religious system. Islam gives them their robe, form, and vocabulary, but the central idea of Isma'ilism is ancient. It is an Islamic parallel to Gnosticism (an alternative dualistic form of Christianity), and it is connected to the Hellenistic Pagan Gnosticism and Manichaeism. A further parallel to the appearance of Isma'ilism in Islam is the appearance of Manichaeism between the religions in China as a result of the influence transferred by Turks from Central Asia. This developed Ming Chiao (the religion of conscience) which are dualistic forms of Buddhism (the Buddha of Light) and Taoism. What Isma'ilists refer to as Allah (what is the name of God for Muslims), is nothing else but a first emanation or hypostasis. More about the Assassins on: Cyril Glasse, Enciklopedija Islama, AltaMira Press, Walnut Creek, CA, USA, 2002 (Prevod na bosanski jezik, Sarajevo: Libris, 2006. str. 271-279).

${ }^{6} \operatorname{Ibid}(\mathrm{x}) .54-57$.
} 
The terror tactics, Israel successfully used to gain independence even before the WWII, in the Palestinian rebellion against British rule. The riots were led by Jewish terrorist organizations Irgun and Stern Gang. These organizations were still during the war, and tried not to stand out in their activities, but already during 1944, three bombings happen at the same time, and two years later, the King David Hotel was mined, where the British central office was located ${ }^{7}$. Such actions resulted in solidarity with the groups fighting for freedom and they got support and help from mighty allies. During 1948, this process ended the British rule in Palestine, but opened up the volcanic core, that is, the foundation of Israel. Similar terrorist attacks encouraged other groups to use similar methods in the future. Modern Israel did not stop using the same methods, even from the position as a country (terrorism through revenge, aggression, and terror among Palestinians).

During February, 1994, Jewish extremist, Brauch Goldstein, the follower of rabbi Kahane, massacred 29 people in a crowded mosque in Hebron, and a year later, the Prime Minister Yitzhak Rabin was killed by a Jewish extremist who claimed to fulfill God's orders. Without doubt, Israel is one of the leaders in terms of state terrorism. Such state resulted in Palestinian terrorist attacks on Israeli population, almost daily, because they see Israel as their enemy, not only a certain number of them ${ }^{8}$.

Next to Israel, when talking about the religion of the Middle East, it is necessary to mention that the Arabian political sentiment was moulded by French and British colonialism, and the Arabian failure to prevent the establishment of Israel as a country. The relationship of Israel towards Palestinians, in later times, as well as direct help of the USA in their efforts, will aid to the appearance of Arabian jihad (Sageman, 2004, p. 36) which will later become Al-Qaida.

Arabian jihad fought against foreign occupiers and communist forces in their homeland, and spread jihad back in their homes. However, such approach will change after February 23, 1998, after the establishment of the World Islamic Front, when Osama bin Laden declared war against Jews and crusaders. With this move the priorities from "the nearby enemy" shifted to "the far enemy". Not long after such instructions, the Al Qaida targets were out of Muslim territory. That way, during August 7, 1998, a double bombing of US embassies in Nairobi and Dar es Salam marked a new milestone in the operations of Al Qaida. This meant that the defensive operations on Muslim soil shifted to attacking operations on non-Muslim soil.

Next to the above mentioned, it would be completely absurd to put an equality sign between the Islamic faith and the terrorism of extremist groups which act in the name of "Arabian jihad". We called it the "Arabian jihad" knowingly, because what its members do in their operations (killing of innocent people, disruption of peace on Earth), such crimes and criminals do not have a place in Islam. This is a barbarian and ignorant concept ${ }^{10}$. Islam has a universal mission which is reflected in liberating all humans of serving anyone else but God. In other words, the mission of the people is to end all injustice on Earth by aspiration to God. This included and includes leaving violent political systems which prevented people to choose their faith. Islam could not and cannot be forced upon, but this does not mean that Muslims need to tolerate political and material forces which deny human freedom to Muslims and other citizens. Islam is not a heritage of a certain race or country; it is the religion of God and is intended for the whole world. Jihad, which is promoted by Islam (the

\footnotetext{
7 Taken from: Denis Rižvić: Terorizam, see: http://www.novihorizonti.com.

8 Ibid (v). P. 62.

9 Such relationship resulted in the establishment and foundation of two different groups: "Al Jihad Islamiyah" which is often called Egyptian Islamic Jihad-EIJ and JemmahIslamiyah or the Egyptian Islamic Group-EIG.

${ }^{10}$ Ignorance and the state of barbarism that prevailed on the Arab peninsula before Islam.
} 
Great Jihad) represents non-violent aspiration to live a normal Muslim lifestyle, in accordance with God's will and a life which includes the five pillars of Islam ${ }^{11}$.

The second mentioned is especially manifested in the USA, where mass media rushed to the conclusion that behind the bombing in Oklahoma stands one Islamic group. The situation is not better in Europe. Such one-sided reporting provides a great media space, even though in many cases they are not verified and are wrong. These reports can be characterized as "if an explosion or a bombing happens anywhere and at any time, Islamists or Islamic terrorists stand behind them". Such attitude is hypocritical and does not aid in solving of the terrorist attack issues.

However, not everyone has such an attitude. There are a great number of researchers and scientists in the world who tend to remove the religious prefix of terrorism. We join this group, and with this paper we would like to give our contribution to this hypothesis.

Two of the leading authors in the world, Lloyd Pettiford and David Harding, in the book Terrorism- $a$ New World War, try, and in our opinion they are successful, to remove the prefix "Islamic" from the word terrorism. They consider that such title for terrorism has no place. They do not contest that Islam, by misuse, is used as fuel in recruiting suicide bombers in the occupied Palestinian territories, but at the same time, they argue that Jewish terrorist groups are often "fed" by Judaist doctrines (Pettifrod \& Harding, 2003). A whole spectre of left-wing teaching, the Christian doctrine, right and left-wing orders of Latin America, "participated" in the creation of ideological profiles of different forms in terms of terrorism, especially during the XX century. Because of that, according to the authors, any emphasis of the Islamic component in terrorism is not fair.

The fact that terrorism, especially during the last few decades, more often occurred in countries where Muslims are the majority, or that the perpetrators of terrorist acts mostly were Muslims, tells more about the harsh conditions of that part of the world, tells more about almost no freedom of choice, and a deep feeling if injustice spread among the population that feels betrayed from the regimes in their countries, but also from the part of the world which likes to call itself free or democratic, thinking firstly about USA.

Noam Chomsky, one of the opponents of the USA foreign policy used the dishonest politics of the American government towards Central America, claimed that the USA are the leading offender in terms of human rights and the instigator of terrorism in the world. Chomsky, in his book written during the Cold War, The Culture of Terrorism (1988), claims that "Regan's administration developed a complex international terrorist network, without a precedent in history as far as I know, and used it in various purposes".

Lloyd Pettiford and David Harding (2003) consider that it is needed to avoid the polarization to "us" and "them". In terms of terrorism there are no "only good" and "only bad" guys. When talking about terrorism, the causes cannot be found only in evil, nor is the solution only in good. "The causes are in the multiple evil of world politics. Until these issues are not dealt by those who have power, until there are more good deeds, terrorism will be our faith".

If we compare the book Terrorism-the New World War with the work of Noam Chomsky Pirates and Emperors, Old and New, where Chomsky, through the talk about terrorism, completely criticizes the American foreign policy (and he does that for many years now) on one side, and in the short essay of Samuel Huntington,

\footnotetext{
11 The five pillars of Islam are: belief that there is no God other than Allah, and that Muhammed is his prophet; Regular prayers - five times per day; to help the poor; fast during the month of Ramadan (the ninth month in the Islamic calendar) and Hajj - every Muslim, if able, should at least one go to Mecca during the time of the Hajj.
} 
"The Era of Muslim Wars", we can see that Lloyd Pettiford and David Harding try to place themselves somewhere between the other two authors. Surely, their opinions are closer to Chomsky; their left-winged background comes to an expression, but not in the way Chomsky does it, especially not with complete criticizing, focused entirely on the USA. Unlike Huntington, this duo does not potentiate the prevailing Muslim fault in the story, making it only a small part of the talk about terrorism. This is exactly where they are different from Chomsky, who in all of his "Americanism", used to flirt with the prejudices towards Muslims and the Muslim world. The opinions of the two authors are closest to Professor Howard Zinn, from the University of Boston, who wrote the famous book A People's History of the United States.

In his book Terrorism and War, Professor Zinn, through questioning of the contemporary political and social issues of the modern world: globalization, militarization, democracy and citizen rights, media manipulation and government arrogance, tries to, like Pettiford and Harding, explain what is hidden behind the paroles: "War against terrorism", "Unity of a nation", and "Just war". When we mentioned Huntington, it is necessary to understand how he views terrorism and how does terrorism have a place in his analysis. In his paper "The Clash of Civilizations" he believes that "direct conflicts between great states can develop a huge level of violence, and the same could happen with conflicts on the divisions where great countries of different civilizations help their smaller allies form the same civilization" (Huntington, 1993). Such opinion confirms that changes in terrorism can occur almost or at the same time like by any other form of violent political conflicts anywhere in the world.

Next to the mentioned authors, there are those who supported the views that terrorist acts are connected to social and political movement. They consider that terrorism is a product of such movements, and not the initiator of social and political movements. To be more precise, such terrorist actions are a final indicator of political changes (Tarrow, 1994).

\section{Conclusions}

By considering security implications of this new reality, it is necessary to develop international laws in the future, in terms of defining new rules and standards in the fight against politically motivated violence and terrorism. Of course, we should not lose the fact that these efforts will be under the influence of globalization and that it will resort to the means of coercion. The fact is that globalization practically changed terrorism inside of the international community, and it will be hard to reach simple and unique rules.

Viewing from a global aspect, management of state or interstate legal answers for terrorism can not only be concentrated on "order", because of the reason that political violence is an unwanted, maybe even a chronic consequence of different interest groups. Such sources of conflicts need to be narrowed down to a frame which enables a dialogue.

This deliberation about terrorism, as well as the mentioned opinions of the authors, and a considerable left-wing, and, in moments, American attitude when they talk about the causes of terrorism, can be something others will not agree with. Does the goal justify the means? Is the danger real? And is there enough real danger to justify the spending of 10 billion $^{12}$ in dollars which could be used somewhere else? There are many causes of suffering, torment, and death which could surely be reduced with investment in their prevention and solution.

\footnotetext{
${ }^{12}$ As a solution for security threats towards the UNSA, the Clinton administration that $28 \%$ of the 10 billion dollars from the budget intended for the fight against terrorism, during 1999-2000, is to be directed towards the fight against chemical, biological, and information terrorism... See: Max. Taylor i John Horgan: Terorizam u budućnosti, Golden marketing, Zagreb, 2003 , str. 138.
} 
Let us take traffic accidents as an example $\left(42,420\right.$ dead in USA during $\left.1997^{13}\right)$, diseases $(725,790$ people died as a result of heart diseases during 1997 in the USA, and 537,390 died because of cancer ${ }^{14}$ ), or even victims of "regular" murders $\left(15,551\right.$ died in the USA during $\left.1995^{15}\right)$. Based on these facts, we consider that investment in any of the mentioned areas would save much more lives than in investing to the prevention of a hypothetical danger of terrorism. However, considering that, authors alone, whose opinions we analyzed earlier, leave the possibility that they might have been wrong in certain assessments and that they were too strict toward certain phenomenon of that part of the world we call democratic.

Therefore, this paper dedicated to terrorism definitely has a goal to make you think. The words of Professor Howard Zinn, spoken after September 11, 2001, could be of great help: "To try and explain and understand terrorism does not mean to look for justification for its existence. However, if you never try to explain anything, you will comprehend nothing".

\section{References}

Abazović, M. (2002). National security, introduction and basic concepts. Sarajevo: FKN.

Anić, V., \& Goldstein, I. (2000). Rječnik stranih riječi (Foreign word dictionary). Zagreb: Novi Liber.

Bjorgo, T. (1997). Racist and right-Wing violence in Scandinavia. Oslo: Tano Aschenhong.

Dimitrijević, V. (1997). Strahovlada (Reign of terror). Beograd: Dosije.

Glasse, C. (2002). Enciklopedija Islama (The Encyclopedia of Islam). USA: AltaMira Press.

Huntington, S. (1993). The clash of civilizations? Foreign Affairs.

Klaić, N., Domović, Ž., \& Anić, Š. (1985). Foreign word dictionary. Beograd: IKP Evro.

Kržalić, A. (2017). Vanjska i sigurnosna politika Europske unije (Foreign and security policy of the European Union). Sarajevo: Udruženje nova sigurnosna inicijativa.

Kržalić, A., \& Veladžić, N. (2016). Organizovani kriminal, kriminološko-sociološki aspekti (Organized crime, criminological and sociological aspects). Sarajevo: UNSI.

Laqueur, W. (1997). Terrorism. London: Weidenfeld \& Nicolson.

Modly, D., \& Korajlić, N. (2002). Kriminalistički rječnik (Criminalistic dictionary). Tešanj: Centar za kulturu i obrazovanje.

Pettifrod, L., \& Harding, D. (2003). Terrorism-New world war. London: Arcturus Publishing Limited.

Sageman, M. (2004). Understanding terror networks. Pennsylvania: University of Pennsylvania Press.

Šikman, M. (2006). Terorizam-aktuelni i mogući oblici (Terrorism-Current and possible forms). Banja Luka: Visoka škola unutrašnjih poslova.

Spahić, M. (2014). Opsada Sarajeva 1992-1996 (The siege of Sarajevo 1992-1996). Zenica: Vrijeme.

Tarrow, S. (1994). Power in movement. New York: Cambridge University Press.

Taylor, M., \& Horgan, J. (2003). Terorizam u budućnosti (Terrorism in the future). Zagreb: Golden Marketing.

Venner, D. (2005). Povijest terorizma (History of terrorism). Zagreb: Alfa.

Wilkinson, P. (2002). Terorizam protiv demokacije (Terrorism against democracy). Zagreb: Golden Marketing.

\footnotetext{
13 The New York Times World Almanac and Book of Facts, 1999, p. 876.

14 Ibid.

15 Ibid. P. 880.
} 